\title{
Voluntary Body Donation Programs: A Timely Awakening
}

\author{
Gaikwad MR ${ }^{1 *}$, Gaikwad RD² and Haldar $\mathrm{A}^{3}$ \\ ${ }^{1}$ Additional Professor and Head, Dept of Anatomy, AIIMS, Bhubaneswar, Odisha, \\ India \\ ${ }^{2}$ Prof and Head, Dept of Physiology, Santhiram Medical College and Hospital, \\ Nandyal, Andhra Pradesh, India \\ ${ }^{3}$ Senior Resident, Dept of Anatomy, AIIMS, Bhubaneswar, Odisha, India
}

*Corresponding author: Manisha R Gaikwad, Additional Professor and Head, Dept of Anatomy, AIIMS, Bhubaneswar, Odisha-751019, India, Tel: 9438884040; Email: anat_manisha@aiimsbhubaneswar.edu.in

\section{Editorial}

We have the read the research article entitled "Body donation Program for the Anatomical teaching: The perception by Brazilian students" by da Costa Sobrinho OP, et al. published in your esteemed Journal of Human Anatomy 2018, 2(2):000125. We want to congratulate the authors for the published research article and addressing the common scenario throughout the globe about voluntary body donation programs and scarcity of cadavers for Anatomy teaching.

The procurement of cadavers for learning Anatomy in the past was by way of digging graves to steal bodies or unclaimed dead bodies [1]. But with civilization and technology advancement the standard of living increased and this lead to shortage of cadavers [2]. Most of the universities and medical schools throughout the world are facing difficulty in procuring cadavers for Anatomy teaching. Human cadavers are the gold standard and the best possible means to study 3-dimensional morphology of organs and correlate it with the functions [3].

In this article they have conducted a survey to know about the awareness / perception of the Body donation in the Brazilian students which they could by way of questionnaire study. As the need of cadavers for Anatomical teaching is the best mode of studying the subject [4]. How do the students perceive donation of one's own body for research purpose could be best gauged from this Brazilian study. It could also test the knowledge, attitude the students had about the body donation program in Brazil. Due to this initiative the body donation program will gain momentum and to some extent the shortage scarcity of cadavers in medical schools for teaching 3 dimensional anatomy will be tackled [5].

The Laws, provisions and rules governing the destination of the donated bodies for human Anatomy teaching does differ from one country to other. Creating awareness about Body donation programs in Brazil will help to motivate the students and people at large about how to shun the myths and religious beliefs on donation of one's own body for medical research [6]. As donated cadavers are the best source of material for Anatomical teaching and research in medical schools [7]. The strategies need to be chalked out and the people to be approached should be done in a well planned manner by way of donor profiles for maintaining effective body donation programs. Fruitful implementation of the body donation program will also help for conducting the Hand's on cadaveric workshops for doctors of surgical specialities to hone the operative skills and for students to prepare good quality museum specimens [8]. The knowledge of Anatomy gained through cadaveric dissection is the best mode for medical practice for future surgeons and doctors [9]. This can best be achieved through the use of donated bodies by widespread, publicized and institutionalized voluntary body donation programs $[10,11]$. 


\section{References}

1. Jones DG (1995) The Human Cadaver: An Assessment of the Value We Place on the Dead Body, Perspectives on Science and Christian Faith 47: 43-51.

2. Joana ED, Marcus VA, Ana Paula CA, Rodrigo FZ, Edson GS, et al. (2011) The Dados preliminares de um modelo de programa de doação de corpos: Programa de Doação de Corpos da UFCSPA. Revista da AMRIGS Porto Alegre 55(1): 7-10.

3. Morar S, Dumbrava DP, Cristian A (2008) Ethical and legal aspects of the use of the dead human body for teaching and scientific purposes. Revista Romana de Bioetica 6(4).

4. Ajita R, Singh YI (2007) Body donation and its relevance in anatomy learning - a review. J Anat Soc India 56(1): 44-47.

5. Hasan T (2011) Is dissection humane? Journal of Medical Ethics and History of Medicine 4: 4.

6. Brasil (2012) Ministério da Saúde. Conselho Nacional de Saúde. Resolução n. 466, de 12 de dezembro de 2012. Aprova diretrizes e normas regulamentadoras

\section{Journal of Human Anatomy}

de pesquisas envolvendo seres humanos. Brasília, Diário Oficial da União, $12 \mathrm{dez}$.

7. Shaikh ST (2015) Cadaver dissection in anatomy: the ethical aspect. Anat Physiol 1: S5-7.

8. Rocha AO, Pedron J, Simonetti L, Girotto Marina, Thomaz L, et al. (2015) The Role of Body Donation Programs in Improving Anatomy Education. Faseb J 29(1): 547.

9. Turney BW (2007) Anatomy in a modern medical curriculum. Ann Royal Coll Surg Engl 89(2): 104-107.

10. Rocha AO, Tormes DA, Lehmann N, Schwab RS, Canto RT (2012) The body donation program at the federal university of health sciences of Porto Alegre: a successful experience in Brazil. Anat Sci Educ 6(3): 199-204.

11. Cornwall J, Stringer MD (2009) The wider importance of cadavers: Education and research diversity from a body bequest program. Anat Sci Educ 2(5): 234-237.

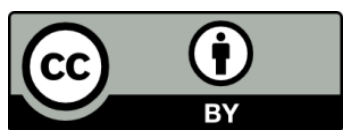

